Abstracta Iranica Abstracta Iranica

Revue bibliographique pour le domaine irano-aryen

Volume 40-41 | 2019

Comptes rendus des publications de 2017-2018

\title{
George Lane (ed.). The Phoenix Mosque and the Persians of Medieval Hangzhou
}

\section{Yuka Kadoi}

\section{(2) OpenEdition \\ 1 Journals}

\section{Electronic version}

URL: http://journals.openedition.org/abstractairanica/47932

DOI: 10.4000/abstractairanica.47932

ISBN: 1961-960X

ISSN: 1961-960X

Publisher:

CNRS (UMR 7528 Mondes iraniens et indiens), Éditions de l'IFRI

\section{Electronic reference}

Yuka Kadoi, "George Lane (ed.). The Phoenix Mosque and the Persians of Medieval Hangzhou", Abstracta Iranica [Online], Volume 40-41 | 2019, document 5, Online since 15 July 2019, connection on 16 April 2021. URL: http://journals.openedition.org/abstractairanica/47932 ; DOI: https://doi.org/10.4000/ abstractairanica. 47932

This text was automatically generated on 16 April 2021.

Tous droits réservés 


\title{
George Lane (ed.). The Phoenix Mosque and the Persians of Medieval Hangzhou
}

\author{
Yuka Kadoi
}

\section{REFERENCES}

George Lane (ed.). The Phoenix Mosque and the Persians of Medieval Hangzhou. London:

Gingko Library, 2018, 273 p., 48 ill., ISBN: 9781909942882

1 Edited by George Lane, The Phoenix Mosque and the Persians of Medieval Hangzhou intends to contextualise one of the historic mosques on the coastal region of East China and their related cultural relics, particularly tombstones and stelae, some of which are masterfully carved and inscribed. Located in Hangzhou (the capital of the Southern Song Dynasty) and known as the Phoenix (Fenghuang) Mosque, this architectural complex is uniquely blending Chinese and Islamic styles. Although its original foundation can be traced back to the late thirteenth century, the Phoenix Mosque unfortunately suffered destruction in the 1920s and was later rebuilt according to its original plan.

2 This book consists of six chapters. Apart from the first chapter (by Chen Qing), the rest are all prepared by the editor. Half of the pages are occupied by two appendixes: Appendix I (Tombstones: Translations and Transliterations) is compiled by the late Alexander (Sandy) Morton, while Appendix II (The Islamic Stelae of Hangzhou) is introduced by the editor and translated by Florence Hodous. All figures are published in black-and-white, but these monochrome reproductions serve to enhance the legibility of inscriptions on tombstones.

3 What makes this study noteworthy is the catalogue of tombstones with Persian and Arabic inscriptions (see Appendix I). These tombstones tell the biographies of Persian- 
speaking Muslims (mostly from modern-day Iran but also from the wide Persian cultural lands) who flocked to China from the other end of the Mongol Empire.

4 The Phoenix Mosque and the Persians of Medieval Hangzhou deserves to be seen as one of the key publications that not only increases our knowledge of the cosmopolitan, multicultural landscape across the Mongol Empire but also awakes a fresh interest in the survivals of Muslim architectural culture in East Asia, one of the understudied fields of research.

\section{AUTHORS}

\section{YUKA KADOI}

University of Vienna 